\title{
Examination of Lifelong Learners' Preferences for Learning Materials and Methods within the Context of Various Demographic Characteristics
}

\author{
Hakan Altınpulluk ${ }^{1 *}$, Hakan Kılınç², and Mehmet Fırat ${ }^{3}$ \\ ${ }^{1}$ Anadolu University, Open Education Faculty, Turkey \\ ${ }^{2}$ Anadolu University, Open Education Faculty, Turkey \\ ${ }^{3}$ Anadolu University, Open Education Faculty, Turkey
}

\begin{abstract}
.
The aim of this study is to analyze the relationship between lifelong learners' preferences for learning materials and methods according to age, gender and working status variables. Since lifelong learners' preferences for learning materials are examined according to certain variables, the relational survey model, which is used in descriptive research, was considered appropriate to implement in this study. The study group of the research consists of 608 lifelong learners, who study at their second universities at least and receive education within the scope of second university without examination in the Faculty of Open Education, Anadolu University. The data were analyzed by using custom tables in SPSS 24.0 package program and descriptive statistics such as frequencies and percentages were used in the analysis of the data. The findings obtained from the statistical analyses of the research questions were presented under six sub-headings.
\end{abstract}

Keywords: lifelong learning, learning materials, learning methods. 